\title{
Research on Integration of University Innovation Entrepreneurship Education and Professional Education
}

\author{
Yingzhen Xue \\ Xi'an International University, Business school, Xi'an, Shaanxi ,China, 70077, China
}

Keywords: Integration, University, Innovation Entrepreneurship Education, Professional Education

\begin{abstract}
Under the innovation-driven social transformation and economic development trend, how more effective and practical way to cultivate different types of innovative talents, has become an important task of China's reform and development process of Universities face. Diversity, practical and comprehensive characteristics of entrepreneurial education make it an effective means to cultivate innovative talents. Entrepreneurship Education in Chinese Universities should be based on their own school characteristics and advantages of Enterprise Education to develop school-oriented, based on long-term development strategy for entrepreneurship education, entrepreneurship education and to strengthen the integration between professional education, build entrepreneurship education teacher growth platform, and gradually form each distinctive entrepreneurial education system.
\end{abstract}

\section{Introduction}

Entrepreneurship education is a new educational mode with high socio-economic development, while labor facing employment, re-employment under the enormous pressure of the background and promotes the development. It is the general trend of the world development of higher education. The main task is to higher professional education, how to adapt to the requirements of the development of higher education, entrepreneurship education into professional education is a new issue worth discussion and research.

\section{The Problems of Entrepreneurship Education}

The basic content of entrepreneurship education is to develop and improve students' entrepreneurial qualities that students' ambitious, aggressive, pioneering spirit, the spirit of innovation, as well as engaged in a cause, business, business planning skills and psychological quality education activities. Currently, entrepreneurship education in Chinese universities mostly around how to start a series of quality and ability of enterprise and entrepreneurship needs carried out. There are problems of entrepreneurship education in four areas.

First, set entrepreneurship education as the only integral part of the Employment Education. Many entrepreneurial education in universities still remain in terms of skill, psychology, policy, situation analysis, guidance, the students deep sense of entrepreneurship, education, entrepreneurship and entrepreneurial capacity has not yet attracted attention, no systematic education system.

Second, entrepreneurship education in all types of entrepreneurial activity based. Currently entrepreneurship education in universities mainly Communist Youth League organizations and the student body set up by management to entrepreneurship lectures, business plan competitions and associations and other extracurricular activities to expand, but only a few people participated in these activities, and the effect of education is not ideal .

Third, entrepreneurship education and professional education out of touch. Many of entrepreneurship education in colleges and universities to carry out the process, failed to start basic knowledge, develop basic quality professional education with organically combined, also failed to entrepreneurship education into a professional whole process, although some colleges and universities 
opened with entrepreneurship education related courses, but entrepreneurship education has not been integrated into the teaching system in general.

University Entrepreneurship Innovation Education and Professional Education

Innovation and entrepreneurship education in the 1980s Western countries and the development of a new educational concepts and models, it is to cultivate entrepreneurial talents as the goal, so that students have a sense of innovation and entrepreneurial spirit, knowledge, skills and abilities through innovation and entrepreneurship education, and actively adapt to the psychological quality of society. College entrepreneurship and innovation education refers to combining professional education to the students in teaching entrepreneurship and innovation knowledge, enhance entrepreneurship and innovation awareness, foster entrepreneurial spirit of innovation and improve entrepreneurial innovation ability, so that students boldly go after graduation society, realize their own businesses or achieve innovation at work an educational model of self-development.

Education College based general education for all based on the premise, through the expertise of a subject system of teaching and learning, training and education have certain professional knowledge and expertise of personnel. Professional education have a certain tendency career goal is to train specialized personnel to adapt to the needs of society. Over the years, China's higher education to professional education, training a large number of specialized personnel for various industries, professional education has been standardized development, the formation of a more systematic, comprehensive professional education system. But with the social and economic development, this single model of professional education cannot meet the quality requirements for talents, coupled with our innovative entrepreneurship education is still relatively weak, how to develop students' entrepreneurial innovation capacities through professional education, the two who combine to become an issue of higher education need to be resolved.

The Necessity of Integration for Entrepreneurship Innovation Education and Professional Education

In China, the enterprise education has been advocated by the individual scholars, individual schools becoming fragmented practice at the government's request, the appeals and social and Degree College Education. However, compared with foreign enterprise education, entrepreneurship education in Chinese universities is still in its infancy. Educational research Universities Entrepreneurship is not only further promote entrepreneurship education in Chinese universities into science as soon as possible, rapid and healthy development track requirements, but also to expand our concept of education, strengthen the connotation construction of higher education, better play on higher education theory Practical guidance for Higher Education in the inevitable requirement.

Universities Entrepreneurship education is not only to adapt to economic and social development of an educational philosophy, but also a training mode innovation of college talent, it is important to break with the way the University of personnel training talent market demands these problems. + Inferior to grab a seat made no chair, + face the most difficult, only harder, employment situation, how to further promote their own businesses slowed College employment pressure, it is a hot topic governments, universities and community-wide concern. Therefore, the integration of university entrepreneurship education professional education to more effectively guide students to actively monitor the progress of the professional field and innovative changes, the boot Universities concerned areas of expertise frontier issues, so that the innovation itself becomes a part of their acquired knowledge, optimization knowledge structure of college, establish entrepreneurial awareness, foster entrepreneurship and improve the quality of employment and employability, very important practical significance. 


\section{The Route Choice of University Entrepreneurship Innovation Education and Professional Education}

Change the education concept and strengthen the concept integration of entrepreneurship innovation education and professional education. Fusion path to seek innovative entrepreneurship education and professional education and to strengthen the integration of professional education must foster innovation and entrepreneurship education in one educational philosophy, only to do the integration of both educational philosophy, to be coordinated with professional education and entrepreneurial innovation teaching time to achieve the goal of education,

First, we must change the concept of a single professional education, fully understand the importance of innovation and entrepreneurship education, entrepreneurship and innovation education is to train entrepreneurial talents as the goal of education is to teach students how to embark on the community, so that students self-innovation through entrepreneurship education entrepreneurial spirit, skills, abilities and self-development, and actively adapt to the concept of employment and social psychological quality, professional education and career with the disciplines differentiation generated, it is instrumental to meet people or social and practical needs the purpose of education is to teach professional skills training and expertise for students to participate in social production as soon as possible to prepare for practice,

Secondly, we need a deep understanding of the dialectical relationship between entrepreneurship and innovation education and professional education, establish the two fusion philosophy of education, innovation and entrepreneurship education is not new content outside professional education, professional education but deepened and specific, professional education requirements of the times and the era of content, educational philosophy permeate the entrepreneurial innovation, integrated into the process of professional education for contemporary college students to help establish a positive sense of entrepreneurship to train students' entrepreneurial spirit, improve the knowledge structure of college students is significant.

Deepening teaching reform, realize the organic integration of entrepreneurship innovation education and professional education. Entrepreneurship and innovation education into the training program, our colleges and universities present innovative entrepreneurship education courses not included in the training program, entrepreneurship and innovation education curriculum has not been included in the regular teaching program is considered to be in formal education, outside Extracurricular time, amateur education, belong to the Communist Youth League Committee or student work department work.

To innovation and entrepreneurship education and professional education and awareness of the concept of integration to improve the conversion capacity and quality on college students, it is necessary to do practical work from the educational practice course structure system and teaching content. On the one hand, we want to permeate professional education in entrepreneurship and innovation in education, innovation and entrepreneurship to strengthen the cross-integration courses and professional courses, according professional must have knowledge of the structure, to build integrated curriculum. In this way, the effective use of classroom resources, expanding the field of application of professional education, but also saves time education, optimizing the teaching content. On the other hand, teachers 'professional courses to change teaching methods to develop entrepreneurial spirit of innovation throughout the entire process of classroom teaching, through a variety of different forms of teaching to develop students' ability to identify problems and solve the problem. Course content can be increased on a comprehensive set course, the creation of interdisciplinary. Interdisciplinary courses broaden students' knowledge, students play non-intelligence factors; creation of innovative entrepreneurship education programs and various forms of lectures, students of business. 
Strengthen the teaching staff, training and integration of high-quality teachers. Schools should pay full attention to innovation and entrepreneurship education faculty building, not in the understanding of the professional education with innovative entrepreneurship education separated. Most colleges and universities do not have specific innovative entrepreneurship education teachers, schools should provide teachers with more home and abroad to participate in entrepreneurship and innovation in the field of academic and research conditions, while some teachers sent abroad with excellent innovation and entrepreneurship education model school or College training.

\section{Promote and integrate professional practical teaching and entrepreneurship innovation practical teaching.}

First, the school should be combined with professional education resources and actively develop high feasibility of entrepreneurial innovation project, the project to expand the practice of entrepreneurship and innovation students, entrepreneurs and provide specific solutions for each project planning, guiding students to entrepreneurship and innovation practices. Venture construction sites and other forms of extracurricular entrepreneurial activities to promote communication and exchange students' entrepreneurial groups. Again, inside and outside the school to strengthen the entrepreneurial base construction for college students to build incubation platform, start a business or to help students master the business management knowledge, enrich students' learning and practice of entrepreneurship, innovation and entrepreneurship to expand the educational function of universities. Of course, the entrepreneurial base construction related to all aspects alone the power of colleges and universities is not enough, we need to attach great importance to the whole society. Schools and local governments should be based on the characteristics of college students, and to give preferential policy support. Only create a good social environment and improve the overall effect, in order to generate more opportunities for entrepreneurship and innovation practice.

\section{Conclusion}

Entrepreneurship and innovation education and professional education is an integral part of the activities of higher education, the purpose is to train high-quality talents with innovative spirit and entrepreneurial ability. We need innovation and entrepreneurship education and professional education combine in a comprehensive professional education in entrepreneurship and innovation permeate education, consolidate the students' professional knowledge base and improve the overall quality of students and entrepreneurial innovation. Integration of innovation and entrepreneurship education and professional education, higher education is a requirement for progress and development, are working together to promote high-level personnel training an important measure, but also the inevitable choice of higher education reform.

\section{Acknowledgment}

1.Natural science foundation research project Funded by Shaanxi province (Program NO: 2016JM1036).

2. 2016 Educational Planning Program of Shaanxi province "From the perspective of the public to raise the influence factors and Countermeasures of college student” (Program NO: SGH16H292)

funded by Shaanxi Provincial Department of education and teaching.

3. 2015 higher education teaching reform project Funded by Xi'an International University (Project NO: 2015B04). 


\section{References}

[1]B. N. Ma, Difficulties and strategies of university entrepreneurship education teachers' construction, J. China Higher Education Research. 44 (2010) 146-147.

[2]H.X.Zeng, School entrepreneurship education theory and practice, J. Educational Research. 18(2015) 55-57.

[3]J.H.Xue, The integration of university entrepreneurship education and professional education, J. Educational Research, 32(2012) 189-190.

[4]Y.J.Qi, State College to teach entrepreneurship development challenges and strategies, J, Educational Research, 4(2007) 38-40.

[5]Y.M.Tian, Entrepreneurship in post-oriented: the restructuring and development of entrepreneurship education in universities strategic choice, J. Educational Research, 9(2013) 142-150. 